\section{Emigré's progress}

Georges Charpak

De la Physique Avant Toute Chose. By Anatole Abragam. Editions Odile Jacob, 15 rue Soufflot, Paris: 1987. Pp. 378. Pbk FF180.

De la Physique Avant Toute Chose is the autobiography of a leading figure in modern physics. Anatole Abragam's contributions to nuclear magnetism have won him high distinctions, while some of his books have been standard works for decades. Then, in 1984, at an age when many physicists are ready to retire, he took pleasure in making a major contribution to the use of muons as probes for condensed matter.

The word 'pleasure' is apposite, for one of the author's designs is to impart to the reader the joy which his discoveries have brought him. He speaks of his experiments with an affection which he sometimes extends to his colleagues. A physicist reading this book will find enlightening explanations of the various milestones along the historical road of nuclear magnetism.

This, however, is only one aspect of the book. The social and scientific rise of the Russian boy, who arrived in Paris in 1925 , was achieved at the cost of a difficult struggle - a struggle which did not have to be faced by those who were privileged to travel the royal road, via distinguished schools, to the few laboratories where advanced research was carried out. It was not until 1945 that, at the age of 30 , Abragam finally found his place in an infant laboratory, at Saclay, where the facilities and talented young colleagues made an ambitious research programme possible. The book leads us around the twists and turns of the author's career, giving a rich account of the history of prewar and occupied France as lived by a child who arrived there at the age of 10 . Abragam was already familiar with the prose of Pushkin, Lermontov and Gogol, so it was not surprising that, after the brief period of acclimatization undergone by all immigrants, he became a highly gifted pupil at a French grammar school.

Abragam paints a flattering picture of the education that he received in Russia, and has remained devoted to Russian culture throughout his life. It was no doubt the fear of a growing policy of proletarian selectivity, which would have barred their son from pursuing advanced studies, that led his parents to emigrate. Abragam's mother was a heroic medical officer in the Red Army and his father the head of a small button factory - in other words, they were bourgeois. His mother went to France with her son and daughter while his father, a 'refusenik' ahead of his time, did not arrive until 11 years later.

A brilliant student in quest of a career, Abragam spent 18 months "wandering around" in medical studies before taking up physics and mathematics, emerging with a degree in science. This account gives us a rather critical description of French secondary and higher education. While severely slating some teachers, the author visits abounding affection and admiration on those, few and far between who did their job well. In 1936 there began, to quote the author, his search for a direction, a guide, and for research companions which took over ten years to find.

There were also the wartime years,

\section{IMAGE UNAVAILABLE FOR COPYRIGHT REASONS}

\section{Abragam - a taste for battle.}

however, under the German occupation, when sheer survival was no mean feat. This part of the history of the occupation, even looked at from the narrow viewpoint of one person's existence, is interesting. After a year's military service, Abragam arrived at Saclay and, like many other young theoretical physicists of the time, owed the opportunity finally to meet teachers and problems equal to his ambitions to a stay abroad. His first period at the Clarendon Laboratory, Oxford, between 1948 and 1950 , was to be decisive. He describes the Clarendon's fruitful environment with affection and humour, and is even now obviously still enthralled by the memory of its archaic customs. 1 feel that scientific historians will greatly appreciate his vivid portraits of some of the great characters in physics whom he thus met, but he also provides the ordinary reader with plethoric descriptions of scientific discoveries.

Abragam's judgements, however, are often brusque and open to question. For example, he criticizes Frédéric Joliot for failing to leave France during the war, which Joliot could easily have done, in order to continue his research in Britain or the United States. In doing so, Joliot would undoubtedly have been able to retain the leading position in nuclear research which he had held before the war. Instead, he elected to stay in France and take part in the Resistance movement. The author may perhaps have failed properly to appreciate the fact that, for a physicist who has enjoyed all the glories of discovery and devotion to science, physics might not prevail above all else and that it might speak greatly in Joliot's favour that he could conceive a passion for a cause aimed at nothing less than re-fashioning the fate of humanity. Moreover, did not the scientific upsurge in post-war France also owe a great deal to those who, by making use of their prestige, created the structures which provided the young physicists emerging from the war with the means of obtaining essential facilities?

Abragam's sometimes cutting criticisms of certain of his contemporaries would undoubtedly have led him into a few duels at the time when academicians' blades were not worn merely as ornaments. $\mathrm{He}$ would nevertheless probably have taken part with enthusiasm, for his literary style often betrays a taste for battle. His sparkling exchanges with the mathematician Réné Thom on the respective roles of mathematics and physics are an example and a delight to read.

Readers may occasionally be confused by the wide variety of avenues along which this book leads them. They will however often smile, and sometimes laugh, at the abundance of anecdotes of which Abragam is an avid collector. So we must render thanks to the author who, via the portraits he draws of all those who have crossed his path, also gives us a glimpse of his own that goes far beyond the description that he gives of himself.

For those who may be irritated to find the events of half a century gauged by their impact on the story of an intelligent little boy from Russia, Abragam quotes in his preface this sentence uttered by a famous humorist: "False modesty is better than no modesty at all".

Georges Charpak is at CERN, CH-1211, Geneva 23, Switzerland.

\section{New journals review}

On 29 September Nature will publish the eighth annual review supplement devoted to science journals. Criteria for inclusion of a journal in the 1988 issue are that:

(i) the first number appeared, or the journal was retitled, between June 1986 and May 1987 (the second cut-off date allows at least three issues of a journal to have been published, the minimum number on which a reasonable judgement can be based);

(ii) it is published at least three times a year; (iii) the main language used is English.

Publishers and learned societies are invited to send four different issues of each suitable periodical, including the first and most recent numbers (if from outside the United Kingdom, by air mail) to: The Review Editor, Nature, 4 Little Essex Street, London WC2R 3LF, England. 